\title{
EFFECT OF CHILDREN'S SERVICES IN GKJW CHURCH GROWTH WIYUNG
}

\author{
Kasiatin Widianto, M.Th. \\ Lilis Setyarini, M.Th. \\ Meniati Hia, M.Th. \\ E-mail: Lilissetyarini@ sttii-surabaya.ac.id, Kasiatinwidianto@ sttii-surabaya.ac.id, \\ Meniatihia@sttii-surabaya.ac.id \\ Sekolah Tinggi Teologi Injili Indonesia Surabaya
}

Abstract. This is to examine the effect of child service on church growth at the Jawi Wetan Christian Church (GKJW) Wiyung Surabaya. This type of research is to explain the influence of child services on the growth of Jawi Wetan Wiyung Christian Church in Surabaya. Respondents who were the sample of this study were 50 people who were members of the Jawi Wetan Wiyung Christian Church congregation in Surabaya. In this study using data analysis techniques, namely methods that relate to the data in the sample, using descriptive statistics that is collecting, summarizing and presenting data systematically based on the sample analyzed with the aim to determine the relationship between a veriabel with other variables namely veriabel $X$ ( independent) and the variable $Y$ (dependent) with the analysis technique is the Pearson correlation technique. From the results of the data analysis test that has been obtained shows that the variable $X$ has an influence with the $Y$ variable which can be seen from the existing value where $R$ Square = 0.595. This means that the influence of children's services on the growth of the GKJW Wiyung Surabaya church has a very influential relationship. With the correlation value $R$ obtained at 0.696 with the influence on $Y$ or $R$ Square (coefficient of determination) $=0.484$. This shows that the percentage contributing to the influence of $X$ on $Y . R$ Square $=0.484$ implies that $48.4 \%$ of the contribution of $X$ to $Y$. $R$ Square ranges from 0 to 1 . Note that the smaller the number of $R$ Square, the weaker relationship $X$ to $Y$. Because the data above the value of $R$ Square is greater then it indicates that the stronger or increasing the relation of $X$ to $Y$. So this can be said that the correlation value or the influence of the relationship on $X$ and $Y$ is good.

Keywords: Child Services, Church Growth

\section{INTRODUCTION}

Speaking about growth is not only limited to plants, but many other things whose existence cannot be separated from growth, among others, such as population growth, economic growth in a region. The same thing happened to church growth, which was related to the church's service to children as one of its members in addition to young people and adults. Concerning church growth, C. Peter Wagner (1990: 31) says, "The growth of the church means everything that includes the matter of bringing people who have no personal relationship with Jesus Christ into fellowship with Him and bringing them into responsible church members". Peter Wongso
(1981: 80) defines the growth of the church as the development and expansion of the body of Christ both in the form of quality, in the form that appears and in its invisible contents. A healthy church produces balanced growth, both quantity and quality, according to Peter Wongso. (2000: 80). The quantity growth in question is the increase in the number of church members. Meanwhile, the church's growth in quality is the growth that results from personal relationships with God. Quality growth goes forward in a better direction, which can be seen from the attitude of love that belongs to the community. Emphasis on quality growth is spiritual 
maturity as evidenced by actions, words and actions based on the character of Christ and realizing the task of the call mandated by Jesus as head of the church, namely serving, fellowship, and witnessing.

Apart from the fact that the church needs future generations, the service activities carried out on children are very important for the church, because through it the church can grow. According to C. Peter Wagner (1996: 101) there are several factors that support church growth: First, the growth of the church through displacement, namely the church in one place that experienced a growing number of members due to members of the church from other churches moved to the church. Second, the growth caused by the preaching of the gospel, namely the growth of the conversion of new souls is the result of the preaching of the Gospel to "those who have not entered the church" so that they can be brought to Christ and become members of the church. And the third factor that causes the church to grow is the biological growth that occurs from children of Christian families and is prepared to become responsible members of the church. Most of the churches around the world grow in this way.

One factor of church growth that cannot be underestimated is the presence and or presence of children in the church. Stephen Tong (2003: 9) said that children are the future of the church, because through the children in one church can be seen in the future of the church. The condition of children who are guided and directed in believing in the Lord Jesus will determine how closeness and also the child can determine the future of the church. Even Stephen Tong (1993: 9) asserts that if there are no children, the future of the church will be a question mark and gloomy. Thus, it is obvious that the presence of children in a church is a very important factor, and should receive serious attention, especially in terms of providing services to them.

The evidence that service to children is a very important service also gets attention from Jesus, as recorded in the New Testament Bible. To His disciples, Jesus said: "Let the children come to Me, and do not hinder them, for those who belong to the kingdom of God are like that" (Luke 18:16). Some of the real things that Jesus showed in this verse, first, Jesus accepted the children who came to Him and instead He forbade His disciples not to prevent the children who came to Him. Second, Jesus places children as models of people who belong to the Kingdom of God. More than that Jesus loved and cared for children, as written in the Gospel of Mark 10:16, which reads: "Then He hugged the children and put His hands on them He blessed them." Even more firmly Jesus stated: "But whosoever deceives one of these little children who believes in me, it is better for him if a millstone is tied to his neck and he is drowned in the sea." (Matthew 18: 6) Some figures from various disciplines science contributes to its views regarding the importance of childhood. Among others, James Clayton "Jim" Dobson, Jr., who was born on April 21, 1936 was an evangelical Christian writer, psychologist, and founder of Focus on the Family (FOTF) in 1977, which he led until 2003. In the 1980s, he entered as one of the most influential speakers for a conservative social position in American public life. He once said that the fifth year in a child's life is the most important time (James Dobson, 45). The same thing was stated by Paul Meier (1983: 60), who stated that children in the first six years of age are the most important times. In the book Christian Family Development 2, Jacob B. Susabda argues that preschool times are actually the primary education periods (1990: 84).

By being aware of the importance of childhood as stated by some of the figures above, it should be able to bring understanding that serving children is a very important service. Which in turn is able to move it to take concrete action, which is willing to give time, energy and life to serve children. It must also be realized that all the most rapid developments occur in childhood. And again, the direction of his life view was formed. The concepts formed at this time greatly affect their adulthood. Childhood is like the foundation of a building that will affect the entire building (Paulus DH Daun, 29), therefore how important and urgent the child must be served. Allowing these children to grow by themselves regardless of service to them is like letting those very important times go by. It's the same as letting the establishment of a house without adequate foundation, and that is very dangerous. Even worse, that children, in their existence as sinners, are at the same time confronted with the death penalty, but in general they are not aware of their existence. Even so, that does not mean they can get away from the deadly snare by being unconscious of their sinfulness. With such conditions really has made it urgent and how important it is to serve them.

\section{RESEARCH METHODS RESEARCH}

In his book Educational Research Methods, Sugiono (2009: 3) states that the population is a generalized area consisting of objects or subjects that have certain quantities and characteristics determined by researchers to be studied and then drawn conclusions. Margono (2000: 121) explains that the population is all individuals who are 
concerned in a specified scope and time. The population determination in this study was 934 people of the Jawi Wetan Christian Church (GKJW) Wiyung Surabaya congregation.

Understanding the sample according to Sugiono (2009: 15) is part of the number and characteristics possessed by the population. If large populations and researchers are not likely to study everything in the population, researchers can use samples taken from that population. While according to Arikunto (1998: 120) explains the meaning of the sample of this study is part or representative of the total (number) to be studied. Determination of the sample in this study were 50 people of the Jawi Wetan Wiyung Christian Church congregation in Surabaya.

\section{Data Collection}

In this study, data collection was carried out through a closed questionnaire. The questionnaire is research tool or survey consisting of a series of written questions, aimed at getting responses from selected groups of people (KBBI). Dewa Ketut Sukardi (1983) stated that questionnaires or questionnaires are data collection techniques that do not require the arrival of direct data sources. What is meant by a closed questionnaire is a questionnaire or questionnaire that presents questions and answer choices so that the respondent can only provide a limited response to the choices given.

\section{Data Analysis}

In this study using data analysis techniques, namely methods related to the data in the sample using descriptive statistics that is collecting, summarizing and presenting data systematically based on the sample analyzed with the aim to determine the relationship between a veriabel with other variables namely veriabel $\mathrm{X}$ and $\mathrm{Y}$ variable with analytical technique is Pearson correlation technique.

Based on the above data analysis techniques, researchers used SPSS (Statistical Product and Service Solutions) which focused on looking at the correlation of $\mathrm{X}$ and $\mathrm{Y}$ where $\mathrm{X}$ is the influence of children's services and $\mathrm{Y}$ is the growth of the GKJW Wiyung church. Based on these facilities it will be seen descriptive and reliability and also valid invalid data, and also to test whether there is a correlation between variables $\mathrm{X}$ and variable $\mathrm{Y}$, both low, medium or high.

\section{RESULTS}

\section{Correlations}

\begin{tabular}{|l|r|r|}
\hline & $\begin{array}{c}\text { effect } \\
\text { ofchild }\end{array}$ & $\begin{array}{r}\text { GKJW Wiyung church } \\
\text { growth }\end{array}$ \\
\hline $\begin{array}{l}\text { services on the influence of } \\
\text { child services }\end{array}$ & 1 & 0,696 \\
Pearson & 50 & 0,000 \\
Correlation Sig. (2-tailed) & & 50 \\
N & & \\
\hline church growth GKJW & & \\
Wiyung & 0,696 & \\
Pearson & 0,000 & \\
Correlation Sig. (2-tailed) & 50 & \\
N & & \\
\hline
\end{tabular}

Based on the results of the correlation test can be explained that the correlation value of $\mathrm{X}$ is very influential on the correlation value $\mathrm{Y}$. Thus if the value of $\mathrm{X}$ is increasing then the value of $\mathrm{Y}$ is also increasing, the meaning is if the influence of child services increases then growth the church is also increasing.

\begin{tabular}{|c|c|c|c|c|}
\hline Model & & & & \\
\hline & $\mathrm{R}$ & R Square & $\begin{array}{l}\text { Adjusted } \\
\text { R Square }\end{array}$ & $\begin{array}{l}\text { Std. Error } \\
\text { of the } \\
\text { Estimate }\end{array}$ \\
\hline 1 &, 696 &, 484 &, 473 & 31,858 \\
\hline
\end{tabular}

Based on the correlation value $\mathrm{R}$ obtained is 0.696 with the effect on Y or R Square (coefficient of determination) $=0.484$. This shows that the percentage contributing to the influence of $\mathrm{X}$ on $\mathrm{Y}$. $\mathrm{R}$ Square $=0.484$ implies that $48.4 \%$ of the contribution of $\mathrm{X}$ to $\mathrm{Y}$. R Square ranges from 0 to 1 . Note that the smaller the number of $\mathrm{R}$ Square, the weaker relationship $\mathrm{X}$ to $\mathrm{Y}$. Because the data above the value of $\mathrm{R}$ Square is greater then it indicates that the stronger or increasing the relation of $\mathrm{X}$ to $\mathrm{Y}$. So this can be said that the correlation value or the influence of the relationship on $\mathrm{X}$ and $\mathrm{Y}$ is good.

\section{ANOVA $^{b}$}

\begin{tabular}{|l|c|c|c|c|c|}
\hline Model & $\begin{array}{c}\text { Sum of } \\
\text { Squares }\end{array}$ & Df & $\begin{array}{c}\text { Mean } \\
\text { Square }\end{array}$ & F & Sig. \\
\hline Regression & 45679,765 & 1 & 45679,765 & 45,008 &, $000 \mathrm{a}$ \\
Residual & 48716,735 & 48 & 1014,932 & & \\
\hline Total & 94396,500 & 49 & & & \\
\hline
\end{tabular}

a. Predictors: (Constant), GKJW Wiyung church growth

b. Dependent Variable: influence of child services The 
table above describes the Anova Test. Anova test is to test whether there is influence or the relationship of independent variables to the dependent variable by using simple regression. The variable $\mathrm{X}$ is child service while variable $\mathrm{Y}$ is the growth of the GKJW Wiyung church. Based on the information in the table, it can be explained that the regression is accepted because the value of $\mathrm{F}$ has a value of 45,008 with a significance of 0,000 , so Ho is accepted, which means the influence of child service is closely related to church growth in GKJW Wiyung.

\begin{tabular}{|l|c|c|c|c|c|}
\hline \multicolumn{1}{|c|}{ Model } & \multicolumn{2}{|c|}{$\begin{array}{c}\text { Unstandardized } \\
\text { Coefficients }\end{array}$} & $\begin{array}{c}\text { Standard } \\
\text { ized } \\
\text { Coeffici } \\
\text { ents }\end{array}$ & T & \multirow{2}{*}{ Sig } \\
\cline { 2 - 4 } & & & & \\
\hline $\begin{array}{l}\text { 1(Constant)church } \\
\text { growth GKJW } \\
\text { Wiyung }\end{array}$ & B & Std. Error & Beta & 5.478 & $199.484,000$, \\
\cline { 2 - 4 } & & $\begin{array}{c}36.414 \\
595,089,\end{array}$ & 696 & 6.709 & 000 \\
\hline
\end{tabular}

a. Dependent Variable: the effect of child service

Value 199,484 is a constant value (a) which means child service $(X)$, very influential on the growth of the GKJW Wiyung church (Y) with a value of 199,484 . With the value of $\mathrm{X}$ and $\mathrm{Y}$ is 0.595 . So it is very clear that the table above explains that when $\mathrm{X}$ has an increase in additional value, $\mathrm{Y}$ will also have an increase in value.

Based on the explanation above, it can be concluded that the variable $\mathrm{X}$ has an influence on the $\mathrm{Y}$ variable which can be seen from the value where $\mathrm{R}$ Square $=0.595$. This means that the influence of child services the growth of the GKJW Wiyung Surabaya church has a very influential relationship.

To prove the correctness of the hypothesis it must be proved by means of the data that has been collected must be tested based on the sample that has been obtained by the researcher. The statistical hypothesis is as follows: $\mathrm{Ho}=$ there is no relation $\mathrm{X}$ with $\mathrm{Y} \mathrm{H} 1=$ there is a relation $\mathrm{X}$ to $\mathrm{Y}$ Based on the existing conditions .060 .06 which is $0.000 \leq 0.06$ indicates that $\mathrm{H} 1$ is accepted. It can be concluded that $\mathrm{X}$ and $\mathrm{Y}$ have visible relationships in the following form, $Y=199,484+X=0.595$. So that means the influence of child services in the GKJW Wiyung church has a relationship to the growth in the GKJW Wiyung church. After the correlation test can be explained that the correlation value of $\mathrm{X}$ is very influential on the correlation value $Y$. Thus if the value of $\mathrm{X}$ is increasing, the value of $\mathrm{Y}$ is also increasing, the meaning is that if the influence of child services increases, the growth of the church also increases. Then it can be concluded that the variable above is variable $\mathrm{X}$ has an influence with $\mathrm{Y}$ variable which can be seen from the value where $R$ Square $=0.595$. This means that the influence of service on the growth of the GKJW Wiyung Surabaya church has a very influential relationship. With the correlation value $\mathrm{R}$ obtained at 0.696 with the influence on $\mathrm{Y}$ or $\mathrm{R}$ Square (coefficient of determination) $=0.484$. This shows that the percentage contributing to the influence of $\mathrm{X}$ on $\mathrm{Y}$. $\mathrm{R}$ Square $=0.484$ implies that $48.4 \%$ of the contribution of $\mathrm{X}$ to $\mathrm{Y}$. R Square ranges from 0 to 1 . Note that the smaller the number of R Square, the weaker relationship $\mathrm{X}$ to $\mathrm{Y}$.

Because the data above the value of $\mathrm{R}$ Square is greater then it indicates that the stronger or increasing the relation of $\mathrm{X}$ to $\mathrm{Y}$. So this can be said that the correlation value or the influence of the relationship on $\mathrm{X}$ and $\mathrm{Y}$ is good.

\section{DISCUSSION}

One of the important factors that influence the growth of the church is the service of children in one church. In this study shows that child services in the GKJW Wiyung Surabaya church have a correlation in terms of the growth of the church. In fact, the results of the study indicate that child service compliance (variable $\mathrm{X}$ ) on the growth of the GKJW Wiyung church (variable $Y$ ) is very good.

\section{CONCLUSIONS AND SUGGESTIONS}

Based on the problems and discussion about the effect of child services on the growth of the GKJW Wiyung Surabaya church, it can be concluded as follows:

a. Based on the results of the research that has been done, it is found that the GKJW Wiyung congregation is largely the result of continuous child or school services starting from the founding of the church until now, as evidenced by the results of the research that has been processed. 
b. Based on the correlation test results can be explained that the correlation value of $\mathrm{X}$ is very influential on the correlation value Y. As explained in the correlation test results can be explained that the correlation value of $\mathrm{X}$ is very influential on the correlation value $\mathrm{Y}$. Thus if the value of $\mathrm{X}$ is increasing then the value of $\mathrm{Y}$ is also increasing, the point is that if the influence of child services increases, the growth of the church will also increase.

\section{Suggestions}

Based on the research, several suggestions for future research and for the church management of GKJW Wiyung Surabaya. The results of the research show that the variable $X$, namely the service of children has a significant influence on the $\mathrm{Y}$ variable, namely the growth of the GKJW Wiyung Surabaya church, it is recommended that the responsible person in the GKJW Wiyung Surabaya church continue to provide motivation and encouragement to the servants who serve children ( Sunday School) GKJW Wiyung continues to be active in serving children. Because, the results of the study indicate that the influence of children's services on GJKW Wiyung church growth is very significant.

For more importance to prove further about the influence of child services on church growth, it is necessary to conduct further research on the same topic where the location of the research can be done in other churches.

\section{REFERENCES}

Arikunto, Suharsimi, 1998, Research Procedure: A Practice Approach. Jakarta: Rineka Cipta.

Berkhof, Louis, 1997, Systematic Theology. Volume 5. Surabaya: Indonesian Evangelical Reformed Institution.

Margono, 2000, Educational Research Methodology. Jakarta: Rineka Cipta.

Wongso, Peter. 1981, The Task of Today's Mission Church. Malang: Southeast Asian Bible Seminary.

Wongso, Peter, 2000, Church Tasks and Present Missions. Surabaya: SURE.

Wagner, C. Peter, 1996, Church Growth Strategy. Malang: Wheat Mas.

Tong, Stephen, 1993, Arsitek Jiwa, Jakarta: Reformed Evangelical Indonesian Institute.
Tong, Stephen, 2003, Soul Architect I. Surabaya: Indonesian Evangelical Reformed Institution.

Prof. Dr. Sugiyono, 2009, Educational Research Methods. Bandung: Alfabeta.

Sukardi, Dewa Ketut 1983, Guidance and Extension of Learning in Schools. Surabaya: National Business

Dobson, James, but the problem of raising children. Bandung: Kalam Hidup.

Meier, Paul D. 1983, Raising Children and Christian Character Development. Surabaya: Sure

Susabda, Yakub B. 1990, Development of Christian Families 2. Malang: Christian Family Development Institution. 